\author{
Kamila Lasocińska*
}

\title{
Kryzys połowy życia - zdobywanie kompetencji autokreacyjnej i dążenie do mądrości
}

\begin{abstract}
Streszczenie: W artykule podejmuję się tematu dążenia do mądrości i potrzeby autokreacji w odniesieniu do osób w wieku średnim. Zakładam, że autokreacja jest ważnym elementem procesu rekonstruowania własnej biografii, uczenia się biograficznego, osobistego rozwoju, a także łączy się z możliwością wewnętrznej przemiany, sprzyja osiąganiu mądrości życiowej. Działania autokreacyjne mają różne znaczenie na różnych etapach życia. Okres średniej dorosłości zakłada duży obszar autonomii sprzyjający świadomemu decydowaniu o własnym losie, ale także sprzyja refleksji i autorefleksji, dokonywaniu przewartościowań i wprowadzaniu zmian. Z drugiej strony jest okresem ukazywanym przez badaczy jako czas możliwego kryzysu i spodziewanego przełomu, który może (a nawet powinien) inspirować do poszukiwań wewnętrznych, odnajdywania nowych możliwości spełniania się, odnajdywania harmonii i nowego kierunku twórczego rozwoju.

Słowa kluczowe: przełom połowy życia, kryzys, rozwój twórczy w wieku dojrzałym, mądrość życiowa, autokreacja.
\end{abstract}

\section{Mid-life crisis - acquiring competence of self-creation and the pursuit of wisdom}

Summary: In the article I take up the theme of pursuit of wisdom and the need for self-creation in a relation to people in middle age. I assume that self-creation is an important part of the process of reconstructing the one's own biography, a biographical learning, a personal development and also connects to the possibility of an inner transformation, promotes the achievement of wisdom. Self - creation activities have different meanings at different stages of life, a period of average maturity implies a large area of autonomy conducive taking conscious decisions about the own fate, but also conducive to the reflection and the self-reflection and making the redefinition

* Akademia Humanistyczno-Ekonomiczna w Łodzi, Katedra Dydaktyki Ogólnej i Psychodydaktyki Twórczości, 90-222 Łódź, ul. Rewolucji 1905 r. nr 64. 
of life goals and introducing changes. On the other hand, it is a period presented by researchers as a time of a potential crisis and the expected breakthrough that could (and should) inspire people to search new possibilities of fulfillment, finding harmony and a new direction for creative development.

Keywords: breakthrough midlife crisis, creative development in adulthood, wisdom, selfcreation.

W artykule podejmuję temat dążenia do mądrości i potrzeby autokreacji w odniesieniu do osób w wieku średnim. Zakładam, że autokreacja jest ważnym elementem procesu rekonstruowania własnej biografii, uczenia się biograficznego, osobistego rozwoju, a także łączy się z możliwością wewnętrznej przemiany, sprzyja osiąganiu mądrości życiowej. Działania autokreacyjne mają różne znaczenie na różnych etapach życia, okres średniej dorosłości zakłada duży obszar autonomii sprzyjający świadomemu decydowaniu o własnym losie, ale także sprzyja refleksji i autorefleksji, dokonywaniu przewartościowań i wprowadzaniu zmian. $Z$ drugiej strony jest okresem ukazywanym przez badaczy jako czas możliwego kryzysu i spodziewanego przełomu, który może (a nawet powinien) inspirować do poszukiwań wewnętrznych, odnajdywania nowych możliwości spełniania się, pragnienia harmonii i twórczego rozwoju.

\section{Specyfika rozwoju w wieku dojrzałym jako potrzeba dążenia do mądrości}

Wiek dojrzały (w tym też okres średniej dorosłości) łączy się z radykalną zmianą warunków rozwoju, ważnym czynnikiem staje się praktyka życia codziennego i jej wymagania. Samodzielna obserwacja i refleksja pozwalają na wykorzystanie praktyki codziennej jako źródła uczenia się. W wieku dorosłym już nie rodzice i nauczyciele, ale sama jednostka ponosi odpowiedzialność za dalsze kierowanie własnym życiem i zadaniami rozwojowymi. Rozwój jest efektem ubocznym codziennych aktywności, trybu życia, rodzaju wykonywanej pracy czy ulubionych rozrywek. Ważnym czynnikiem w wieku dojrzałym staje się autonomia lub względne poczucie autonomii, którą daje niezależność materialna czy kompetencje zawodowe pozwalające na większą swobodę i możliwości decydowania o sobie. Przemiany sprzyjające rozwojowi mogą polegać na budowaniu przez osobę nowych więzi z ludźmi czy kontaktów z instytucjami (Pietrasiński, 1990, s. 44). Rozwój łączy się z podejmowaniem nowych zadań lub z działaniami w nowych warunkach, które wymagają zmiany wykonywania rutynowych 
aktywności. Rozwój w wieku dojrzałym łączy się z kierowaniem życiem, jest podporządkowany wartościom i celom, ale także dążeniom pogłębiającym sens całego życia. Człowiek dorosły ma szansę stawania się coraz lepiej znającym się na rzeczy wspóltwórcą swojej drogi życiowej, zyskiwania na bazie doświadczenia kompetencji biograficznej pozwalającej mu działać w sposób coraz bardziej adekwatny do własnych potrzeb (ibidem, s. 137). Rozwój twórczy osoby dorosłej może się łączyć z jej codziennymi aktywnościami, ale także polegać na przełamywaniu starych wzorców, zmianie wizji własnego życia, głównego kierunku działania, modyfikacji planów i zamierzeń (ibidem, s. 78). Człowiek dorosły doskonali się w takich wymiarach, jak nadawanie wyższej jakości i harmonii własnemu życiu, w pogłębianiu doświadczeń życia wewnętrznego, w ocenie zjawisk oraz w przekraczaniu ograniczeń wyniesionych z poprzednich faz życia (ibidem, s. 46). Rozwój osobisty powinien być wzbogacany działaniami autokreacyjnymi i autorefleksją, aby człowiek dorosły mógł osiągać dojrzałość i zdobywać mądrość życiową.

Mądrość, zdaniem Pietrasińskiego, łączy się z dostrzeganiem problemów i stawianiem pytań, $\mathrm{z}$ trafną samooceną, a także $\mathrm{z}$ dystansem do samego siebie (autodystansem). Mądrość wymaga dojrzałości emocjonalnej oraz gotowości ponoszenia czasem wysokich kosztów dyskomfortu wynikającego z wątpliwości, lęku i niepewności (Pietrasiński, 2008, s. 29). Wiąże się z umiejętnością korzystania z wiedzy i myślenia, z odpowiedzialnością i zaangażowaniem. Jest zdolnością wydawania trafnych sądów na temat ważnych, ale niejasnych problemów życiowych, rodzajem wiedzy dotyczącej natury człowieka i jego relacji z otoczeniem. Istota mądrości nie polega na tym, że człowiek wie wszystko, co trzeba, ale że ma badawczy stosunek do świata, a ponadto zdaje sobie sprawę z ograniczeń swojej wiedzy (Pietrasiński, 1990, s. 40). Mądrość przejawia się w okolicznościach wymagających znajomości ludzi i życia, przewidywania konsekwencji własnych i cudzych działań, podejmowania decyzji w sytuacjach niepewności. Głównym sprawdzianem mądrości są trafne sądy w takich sytuacjach życiowych, które mają częstokroć charakter niepowtarzalny, kiedy osoba nie może się opierać na schematycznym rozwiązaniu sytuacji. Mądrość jest przymiotem, na który składa się wiedza praktyczna nabyta w znacznej mierze jako rezultat osobistych doświadczeń i refleksji opartej na umiejętności głębokiego i wielostronnego myślenia (ibidem, s. 143).

Mądrość ujawnia się zarówno w refleksji, jak i w dostosowaniu się praktycznym do realiów życia. Oznacza umiejętność kierowania własnym życiem, zwłaszcza w sytuacji nagłej zmiany. Nie sama zatem długość życia i obfitość doświadczeń jest warunkiem mądrości, co umiejętność wybrania najlepszej drogi działania, istotnych wartości i rozwiązywania ważnych problemów życiowych. Podstawą osiągania mądrości życiowej jest rozwój osobisty, a zarazem twórczy, oparty na działaniach wspomagających samoaktualizację. 


\section{Zdobywanie kompetencji autokreacyjnej jako możliwość kierowania własnym życiem}

Zmiany życiowe mogą mieć charakter edukacyjny, rozwojowy, kiedy osoba potrafi wprowadzać w swoją aktywność pozytywne modyfikacje oraz przekształcać własne działania i plany. Z kolei świadome wprowadzanie zmian przez człowieka łączy się z kreacją ukierunkowaną na własną osobę (tożsamość), na kształtowanie nowej wizji siebie i swojego życia (planowanie przyszłości).

Według Kazimierza Obuchowskiego człowiek - autor siebie - dysponujący wiedzą o sobie może wyznaczać sobie zadania, dobierać metodę, przez co jego aktywność staje się intencjonalna i autonomiczna. Nie ulega on pragnieniom, ale potrafi je twórczo interpretować i przekształcać w działania celowe. Człowiek-twórca jest zdolny do generowania osobistego modelu świata, projektowania i zmian samego siebie, jest zdolny do rozwoju osobowości i potrafi określić sens życia (Obuchowski, 2000). Tworzenie i kreacja łączą się z umiejętnością odnajdywania się w sytuacjach niedookreślonych, niepewnych, naznaczonych ryzykiem. Dotyczy różnych obszarów aktywności osób dorosłych, w aspekcie autobiograficznym odnosi się przede wszystkim do możliwości zmiany kierunku działania (np. w pracy zawodowej), dokonywania modyfikacji własnych działań i poszukiwania nowych dróg spełnienia, ale także nadawania nowych znaczeń codziennym wydarzeniom.

$\mathrm{W}$ aspekcie autobiograficznym istotne znaczenie ma potrzeba autokreacji stanowiąca ważną kompetencję biograficzną osób dorosłych. Należy zaznaczyć, że jednostka jest formowana przez różne czynniki, na jedne z nich ma wpływ, inne są od niej niezależne lub wpływa na nie w sposób ograniczony. Do tych czynników zaliczamy: kod genetyczny, oddziaływanie środowiska, ale także własne, względnie autonomiczne działania mające charakter współformowania i autokreacji (Pietrasiński, 2008, s. 71). Autokreacja oznacza wspólformowanie się jednostki poprzez swoje osobiste wybory i działania przyjęte z większym bądź mniejszym udziałem własnym. W codzienności zwykłych ludzi jest wielkie pole autokreacji oraz możliwości podejmowania zadań rozwojowych. Codzienność składa się z czynności, z których każda może być inaczej wykonana, każda czynność może mieć coraz to inną strukturę. Wyróżniamy dwa rodzaje autokreacji: intencjonalną oraz nieintencjonalną (ibidem, s. 163).

Autokreacja intencjonalna ma charakter zamierzony, jest to ukierunkowane działanie mające na celu planowaną zmianę siebie i własnych działań (np. zapisanie się na trening asertywności, aktywność sportowa). Współformowanie się intencjonalne polega na świadomym i celowym wpływaniu przez jednostkę na własną drogę życiową i rozwój.

Autokreacja nieintencjonalna ma z kolei charakter niezamierzony, jest wynikiem wyborów człowieka nieukierunkowanych na rozwój, ale mających skutki 
osobotwórcze. Stanowi efekt własnych decyzji życiowych niekojarzonych przez człowieka z formowaniem własnej osoby, tymczasem takie formowanie zachodzi (Pietrasiński, 1990, s. 152). Są to działania nieukierunkowane z góry na pewną zmianę siebie lub swojego życia, natomiast jako skutek uboczny mają charakter osobotwórczy.

Każda czynność wykonywana przez osobę może być rozpatrywana z perspektywy bieżącej bądź z perspektywy biograficznej. Drugi przypadek łączy się z wykorzystywaniem i ujawnianiem kompetencji autokreacyjnej, której przejawem jest koncentracja na perspektywie całościowej zdarzeń z życia, czyli perspektywie biograficznej, rozwijającej się stopniowo pod wpływem podejmowanej przez osobę autorefleksji (Pietrasiński, 2008, s. 165). Kompetencja autokreacyjna pozwala widzieć miejsce i rolę konkretnych czynności podejmowanych przez człowieka w większym systemie, odwołując się do perspektywy życia jako całości. Kompetencja autokreacyjna wymaga przekraczania wymogów chwili bieżącej, presji sytuacyjnej, wymaga dystansu, zmiany perspektywy, analizowania efektów własnych działań i ich konsekwencji. Autokreacja zakłada zatem umiejętność autodystansu i autorefleksję dotyczącą własnych zachowań.

Ważne znaczenie ma dystans do biegu zdarzeń, który człowiek uzyskuje, dokonując na pewnych etapach bilansu swojego życia. Bilans ma znaczenie prorozwojowe, powinien być co jakiś czas powtarzany i pogłębiany. Autodystans sprzyja refleksji nad rozwojowymi aspektami naszej aktywności życiowej (ibidem, s. 137-162). Drugim ważnym czynnikiem wspomagającym autokreację jest autorefleksja. Przedmiotem autorefleksji nie jest świat zewnętrzny, ale sam podmiot i jego przeżycia wewnętrzne. Refleksja i autorefleksja w życiu dorosłym służą jakości życia (ibidem, s. 111-112). Refleksja pomaga łączyć zdarzenia odległe w czasie i pozornie niepodobne, ujmować codzienność z perspektywy pytań egzystencjalnych, pozwala na odnajdywanie strategii i wartości ukrytych za czynami.

Autokreacja łączy się z potrzebą odnajdywania nowych sposobów funkcjonowania w świecie, są one osiągane dzięki dwóm egzystencjalnym procesom: transcendencji i transformacji. Transcendencja to inaczej wytwarzanie sensu i wykraczanie poza własne uwarunkowania lub sytuacje. Natomiast transformacja to dynamiczny proces przetwarzania danej rzeczywistości na nową potencjalność. Kiedy nowa potencjalność zaczyna być aktualizowana, tworzy się przestrzeń dla innych potencjalności (Reker, 2000, s. 41). Według Fromma potrzeba transcendencji nastawiona jest na opanowanie środowiska i na twórczą aktywność, dzięki której życie człowieka staje się celowe, a człowiek zyskuje poczucie, że jest skutecznym twórcą, a nie tylko stworzeniem podlegającym prawom natury (Fromm, 1973). Zdolność do transcendencji polega na przezwyciężaniu urazów, trudnych problemów i świadomym doświadczaniu egzystencji. Bariery, na które człowiek natrafia, uczą go rozumienia własnej skończoności, wymagają konfrontacji z problemem własnej śmierci, która ostatecznie określa sens wszystkich wyborów 
(Oleś, 2003, s. 328). Transcendencja lub autotranscendencja to specyficznie ludzka zdolność, dzięki której życie ludzkie nabiera autentyczności i sensu. Polega na wykorzystywaniu możliwości i przekraczaniu własnych uwarunkowań (Frankl, 1963). Zdolność do transcendencji wyraża się nieskrępowaną możliwością kreowania nowych znaczeń i przekraczania w ten sposób ograniczeń zewnętrznych i wewnętrznych oraz temporalnych granic własnego ,ja” poprzez:

a) rosnące zrozumienie samego siebie i wychodzenie poza aktualne pojęcie o samym sobie;

b) poszerzanie własnej aktywności i wychodzenie poza własne sprawy, ku kontaktom z innymi i zaangażowanie na ich rzecz lub realizacja subiektywnie ważnych idei;

c) tworzenie ubogacających syntez na bazie wspomnień z przeszłości i nadziei przyszłości, prowadzące do bogatszego rozumienia sensu istnienia (Biswanger, 1963; Boss 1977).

Owe przekraczanie własnych możliwości łączy się z potrzebą tworzenia, kreacją, która stanowi ważny dynamizm rozwoju osobowego.

\section{Przełom połowy życia jako szansa ujawniania się tendencji twórczych i uzyskiwania mądrości}

Przełamywanie sprzeczności i rozwój twórczy łączą się z dążeniem do integracji na wyższym poziomie (Dąbrowski, 1979). Dążenie do przekroczenia wewnętrznych konfliktów staje się zadaniem szczególnie istotnym w momentach przełomowych, które mogą przyczynić się do osiągania dojrzałości i mądrości życiowej.

Według Carla Gustawa Junga człowiek nabywa własną indywidualność przez całe życie. Najważniejszym dążeniem człowieka jest dążenie do pelni. Oznacza to, że człowiek w ciągu życia w naturalny sposób zmierza do swojego rozwoju i stara się realizować wszystkie cechy i postawy osobowości (Jung, 1976). Zmiany osobowości na przestrzeni życia zmierzają, zdaniem Junga, ku integracji przeciwieństw. Chodzi tutaj o syntezę funkcji dominującej i stłumionej, dzięki czemu człowiek rozwija nie tylko myślenie, ale także umiejętność korzystania z intuicji, odwołuje się zarówno do uczuć, jak i do racjonalnej oceny sytuacji. Sprostanie temu zadaniu przeobraża jednostkę w istotę bardziej złożoną i twórczą (Pietrasiński, 1990, s. 103). Pełnia ludzkiego funkcjonowania ujawnia się wtedy, gdy człowiek potrafi otworzyć się na świat i dąży do wewnętrznej harmonii poprzez odczuwanie, myślenie, spostrzeganie i odwoływanie się do intuicji. Dzięki temu jest możliwe podejmowanie nowych wyzwań, a także refleksja w stosunku do siebie i świata. Natomiast zatrzymanie się w rozwoju przynosi szkody.

Integracja przeciwieństw wymaga świadomego wysiłku, wiąże się z procesem indywiduacji trwającym całe życie, zakładającym rozwój psychiczny i sta- 
wanie się całością. Zdaniem Junga proces ten ulega szczególnemu nasileniu po przekroczeniu czterdziestego roku życia, kiedy człowiek dochodzi do tzw. ,półmetka". Połowa życia to ważny moment, gdyż zachodzi wtedy przemiana od zaangażowania w działania w świecie, ku autorefleksji i osobistej filozofii życia. Jest to czas możliwych przewartościowań, odejścia od wartości ekspansji, erotyki i spraw materialnych w kierunku wartości duchowych i kulturowych. Człowiek szuka możliwości osiągania wewnętrznej równowagi, harmonii i możliwości wyrażania siebie (autoekspresji). Jest to również moment ujawniania się kryzysu, zaburzeń nerwicowych wynikających z zaniedbywania przez osobę jej szans rozwojowych. Ważne jest dokonanie w tym momencie życia podsumowania, bilansu młodości, przewartościowania i przeprogramowania życia, ujawnianie nowych szans rozwojowych (Jung, 1971).

W wieku średnim w następstwie długotrwałego procesu dochodzi zatem do pełnego rozwoju wewnętrznego jednostki. Pomyślny rozwój w tym okresie życia pozwala osiągać większą niż dotychczas harmonię i niezależność. Każdy wiek ma swoje wartości, przemiany wieku średniego pozwalają zmierzać ku mądrości, ważnym aspektem jest akceptacja przemijania obca młodym ludziom przekonanym o bezmiarze rozciągającego się przed nimi czasu.

Daniel Levinson inspirowany koncepcją Junga podjął się analizy znaczenia kryzysu „połowy życia” dla rozwoju człowieka. Kryzys ten, zdaniem Levinsona, stanowi moment przełomowy w życiu człowieka dorosłego, oznacza diametralną zmianę sposobu myślenia i odczuwania, kontaktowania się z otoczeniem, a także umożliwia przekształcenie programu na resztę życia. Przełom połowy życia łączy się z potrzebą integracji czterech par przeciwieństw: młodości-starości, destrukcji-twórczości, meskości-kobiecości, więzi z otoczeniem-oddzielenia. Pogodzenie tych przeciwieństw jest ważnym wyzwaniem - rozwiązaniem może być dążenie do przemian w środowisku i wykorzystanie energii do robienia rzeczy nowych i twórczych. Przemiany połowy życia to zatem konfrontacja realiów życia z marzeniami młodości, bilans tego, co się udało dokonać, a co stanowiło ważną wartość w okresie młodzieńczym, to także reewaluacja planów i priorytetów. Pojawia się także silna i znacząca potrzeba autonomii i samowystarczalności (Levinson, 1986).

Przełom sugeruje ważną zmianę jakościową, nowe spojrzenie na życie i uchwycenie nowej perspektywy przyszłości. Przemiany połowy życia łączą się często z doświadczeniem kryzysu, chodzi tutaj o doświadczenie osób rozstających się z młodością i wkraczających w wiek średni. Jedni przechodzą ten okres w sposób płynny, stopniowo wprowadzając zmiany w stylu życia, inni wpadają w prawdziwy kryzys, kończący się często próbą odnowy życia (Oleś, 2000, s. 8-9). Różne podaje się granice wieku średniego, nie ma pełnej zgodności, co do tego, jakie lata obejmuje. Najczęściej wskazuje się lata pomiędzy 30-60 rokiem życia, a niekiedy wiek 35-55 lat, czasem 40-60 albo 45-65 lat (ibidem). Okres około czterdziestego roku życia określony został przez Kazimierza Obuchowskie- 
go jako czas stabilizacji, według autora stabilizacja ta polega na tym, że wymagania, jakie człowiek sobie stawia, ulegają już niewielkim zmianom. Wyraźnie zmienia się jednak perspektywa życia. Przeważnie wtedy ludziom staje się znany pułap możliwości awansu zawodowego, statusu społecznego, statusu materialnego. Stabilizacja pojawiająca się w okolicach czterdziestego roku życia polega na tym, że osoba ma poczucie, iż „karty zostały rozdane”, reguły gry ustalone i do czterdziestki gra toczy się w „tym samym zespole”. Po czterdziestce występuje natomiast tendencja do rewizji zasad gry i nowego ich uzasadnienia, a także uzasadnienia samej gry. Wielu ludzi uświadamia sobie, że jest to już ostatnia runda, kiedy można coś (radykalnie) zmienić (Obuchowski, 1985, s. 354).

Ważnym zatem i twórczym doświadczeniem w życiu osób dorosłych może być przełom połowy życia. Pojawiający się wówczas kryzys łączy się z uświadomieniem sobie przez osobę dorosłą, że ma ona coraz bardziej ograniczony czas na własną samorealizację. Moment ten jednocześnie może dla niej stanowić ważny impuls do działania. Kryzys połowy życia, według Levinsona, to ujawnianie tendencji twórczych i moment przełomu sprzyjający podejmowaniu innowacyjnych działań (Oleś, 2003, s. 57). Zmiana ról w wieku średnim łączy się z podsumowaniem młodości, dążeniami autokreacyjnymi, poszukiwaniem siebie i poszerzaniem interpersonalnych odniesień.

\section{Narracja jako kreacja - opowiadanie odzwierciedleniem przemiany $\mathrm{w}$ wieku średnim}

Koncepcje narracyjne mają swoje odniesienie egzystencjalne, gdyż koncentrują się na procesie nadawania znaczeń. Narracyjność i możliwości dialogu wewnętrznego ujawnia złożoność ,ja”, co jednocześnie zakłada względność rekonstruowanych przez podmiot historii i różnorodność programów życia. Narracja jest subiektywna, a ocena kryterium prawdy nie ma znaczenia, ważne jest raczej, jaką historię osoba tworzy i jak ta historia na nią wpływa (Oleś, 2003, s. 365). Narracyjność łączy się z świadomym kształtowaniem siebie, nadawaniem znaczeń, tworzeniem siebie i samookreślaniem, z kreacją tożsamości narracyjnej (ibidem, s. 335). Tożsamość narracyjna tworzy się i zmienia w ciągu całego życia człowieka. W dzieciństwie zbieramy materiał do historii, którą kiedyś utworzymy, w adolescencji nadajemy sens temu, kim jesteśmy, w okresie dorosłości wzbogacamy tożsamość, wpisując $\mathrm{w}$ nią zmiany związane $\mathrm{z}$ postaciami i zadaniami naszego życia (ibidem, s. 347).

Narracje autobiograficzne zawsze mają funkcję interakcyjną, ponieważ zachodzą wobec wyobrażonego bądź rzeczywistego odbiorcy, i funkcję reprezentacyjną, ponieważ komunikują coś ważnego i osobistego. Mają również charakter dialogowy. Treść i forma autonarracji zależą od intencji narratora, ale także od 
jego interakcji z realnym bądź wyobrażonym odbiorcą (Wortham, 2000). Koncepcje narracyjne stoją na stanowisku, że istnieje możliwość realizowania wielu różnych ,ja" w człowieku, inaczej mówiąc: jednostka może konstruować wiele obrazów samej siebie. Każdy z tych obrazów jest częściowy, sytuacyjny i nie pretenduje do jedynego regulatora zachowania człowieka. Kreowanie autonarracji, interpretowanie własnej historii ma charakter twórczy. To nie jest wierny opis faktów, ale pewnego rodzaju indywidualna kreacja autora, który subiektywnie ocenia i interpretuje wydarzenia. Interpretacje te mogą ulegać zmianie na różnych etapach życia. Kreacja często pomija pewne fakty i czasami stwarza nowe (McAdams, 1989; Hermans, Kempen, 1993).

Z kolei narracyjny model Huberta J. M. Hermansa akcentuje zmienność ,ja” jako uporządkowanego systemu znaczeń osobistych i kładzie nacisk na kreatywne możliwości człowieka. Poczucie rozbicia i fragmentacji zarówno doświadczeń, jak i własnego ,ja” jest sygnałem, że osoba gubi sens swojej historii i zaczyna tracić łączność z trwałym i głębokim sensem życia (Mangione, 1993, s. 110). Stan taki może być zapowiedzią istotnej reorganizacji systemu znaczeń osobistych, może być przesłanką nowej formuły sensu życia, albo też zwiastunem zmian prorozwojowych, transgresyjnych bądź dezorganizacji systemu znaczeń osobistych. Jeśli kryzys odgrywa właśnie taką rolę - reorganizacji sytemu znaczeń - to jego efektem może być bardziej adaptacyjne funkcjonowanie człowieka i możliwość dalszego rozwoju. Kryzys jest zarówno szansą, jak i zagrożeniem. Zmiany narracji sygnalizują zmiany biograficzne, odzwierciedlają doświadczenia przełomowe. Teoria dialogowego ,ja” zakłada, że człowiek jest kreatorem znaczeń, interpretuje doświadczenia osobiste i zdarzenia zewnętrzne oraz nadaje im osobisty sens. Wewnętrzna polifonia ,ja”, opierająca się na rozmaitości interpretacji (punktów widzenia), znajduje swoje zwieńczenie w postaci myśli przewodniej, która może nadal pozostawać dylematem. Zmienność punktów widzenia jest charakterystyczna dla polifonii, a jednocześnie jest jednym z przejawów predyspozycji osoby do prowadzenia wewnętrznego dialogu. Nasze ,ja” reprezentuje zatem zróżnicowane punkty widzenia, których wzajemne ścieranie się może aktywizować i angażować autorefleksyjną aktywność podmiotu (Oleś, 2011, s. 146). Zróżnicowanie ,ja”, polifonia i podejmowanie dialogu wewnętrznego odgrywają ważną rolę w kształtowaniu narracji, a także służą jej twórczej modyfikacji.

Zdaniem Dana McAdamsa, w ,połowie życia” zmienia się tematyka osobistej narracji z tego względu, że pojawia się temat śmierci i czasowej ograniczoności życia, ujawnia się wzmożona troska o innych, potrzeba i gotowość pracy na rzecz innych pokoleń, a także wprowadzania ich w dorosłość. Odniesienie do kwestii skończoności życia wzmacnia nastawienie kreatywne osób w wieku średnim, rodzi się bowiem potrzeba wypracowywania nieprzemijających wartości, które można przekazać innym, zwłaszcza młodemu pokoleniu. Tożsamość narracyjna ulega przemianom w okresie średniej dorosłości, pojawia się, między innymi, większa otwartość na zmianę i tolerancja niejednoznacznych ocen, we- 
wnętrzna integracja wyrażająca się zdolnością godzenia przeciwieństw. Kreatywna integracja znajduje wyraz w tematyce rekonstruowanych historii, w których pojawia się więcej elementów na temat życia i jego wartości - właściwość ta narastać będzie $\mathrm{w}$ okresie starości pod kątem dokonywania bilansu życiowego (McAdams, 2001).

Według modelu McAdamsa kreatywność zmienia się po „połowie życia” w aspekcie siedmiu elementów:

a) Aspekt oczekiwań społecznych - dotyczy zwiększającej się troski o młodsze pokolenia.

b) Wiara w siebie i w rodzaj ludzki - oznacza przekonanie o wartości podejmowania wysiłków zmierzających do rozwoju człowieka i wnoszenia wkładu w rozwój społeczności.

c) Kreatywne troski - to myśli na temat tego, jak wspierać młodych ludzi, nadzieję i obawy związane z przyszłością, troska o to, co należy zrobić na rzecz młodych ludzi.

d) Kreatywne pragnienia - wyrażają potrzebę „bycia potrzebnym”, czyli uczynienia czegoś, co ma wartość, z której będą mogli korzystać inni ludzie; wypracowywanie sobie symbolicznej nieśmiertelności poprzez podejmowanie aktywności na rzecz czegoś o nieprzemijającej wartości.

e) Kreatywne zaangażowanie - przejawia się w planach, zadaniach i celach, których sens koncentruje się na wspieraniu młodszego pokolenia.

f) Kreatywne działania - faktyczna aktywność jednostki, wyrażająca dążenia wspierające młodych ludzi i stymulujące ich do rozwoju.

g) Osobista narracja - to historia tworzona przez osobę, opiewająca własne starania i działania na rzecz innych ludzi (McAdams, de St. Aubin, 1992).

Zmiana postrzegania siebie i swojego życia w okresie średniej dorosłości może mieć zatem swoje odzwierciedlenie w autonarracjach osób poddających swoje życie refleksji biograficznej. Opowiadanie własnej historii odzwierciedla zmiany dokonujące się w osobie, ale także perspektywa opowieści o życiu ulega przeobrażeniom pod wpływem przemian życiowych, które często modyfikują perspektywę własnej narracji. Osoba nie tylko komunikuje swoją historię, ale także aktywnie ją tworzy i przekształca, wydobywając nowe znaczenie swojej biografii (McAdams, 2001).

Postępowanie człowieka wynika ze sposobu interpretacji aktualnej sytuacji życiowej (za: Oleś, 2003, s. 319). Nie tylko zatem wydarzenia mają na nas wpływ, ale także znaczenia, jakie im przypisujemy. Przyglądanie się swojemu życiu, różne interpretacje mają odzwierciedlenie w postawach twórczych osób dorosłych. Rozwój osobisty łączy się z refleksją dotyczącą własnej przyszłości, odwoływania się do wspomnień, ale także podejmowania się ich interpretacji. Człowiek zatem ma możliwość wyboru sposobu istnienia poprzez zdolność do kreowania nowych znaczeń. Aktywność narracyjna, a zwłaszcza autobiograficzna ma trudny do przecenienia aspekt pedagogiczny i terapeutyczny (Demetrio, 2000; Tokarska, 
2002). Opowiadanie bądź opisywanie własnych doświadczeń sprzyja ich organizowaniu, rozumieniu, to także okazja do stawiania pytań egzystencjalnych, klasyfikowania wartości osobistych, precyzowania dążeń i świadomego wyboru postępowania. Autonarracja oprócz integrowania i porządkowania systemu znaczeń osobistych oraz ekspresji uczuć służy ocenie zdarzeń i przysparza samowiedzy. Pomaga w uzyskiwaniu wglądu, co ma znaczenie terapeutyczne i rozwojowe. Pomaga konfrontować różne punkty widzenia, planować zmiany, programować własny rozwój oraz wyznaczać cele życia (Trzebiński, 2002; McAdams, 2008), a także dokonywać świadomych przekształceń w obrębie planów i zamierzeń.

\section{Podsumowanie}

Życie człowieka stanowi szczególny przypadek, gdyż osiąga on dojrzałość psychiczną i fizyczną, ale na tym nie kończy się jego rozwój. Natomiast to, co się dzieje dalej w biegu jego życia, pozwala mu na zdystansowanie się i uniezależnienie od tego, co przynależy do procesów inwolucji fizycznej (za: Gałdowa, 2000, s. 53). Rozwój człowieka dorosłego zmierza ku uniezależnianiu się od zasad biologicznej przyczynowości, a zatem łączy się ze zdolnością do przekraczania biologicznych ograniczeń i uwarunkowań (ibidem, s. 59).

Warto też na zakończenie podkreślić, że możliwości samorealizacji i rozwoju człowieka w ciągu życia można, za przedstawicielami psychologii humanistycznej, postrzegać optymistycznie, ale także, odwołując się do teorii krytycznej, zauważyć kulturowe i społeczne ograniczenia. Wedle tej koncepcji, możliwości samorealizacji człowieka mogą być blokowane poprzez kulturę, ta tendencja szczególnie nasila się w epoce zdominowanej przez mass media i konsumpcję. Kultura i społeczeństwo promuje wówczas bowiem zachowania konformistyczne i zgodne z pewnymi tendencjami społecznymi, a życie człowieka jest określane przez najróżniejsze organizacje i instytucje społeczne (w tym szkoła, miejsce pracy itp.). Dążenie do spełnienia jest ukierunkowane jednostronnie i zuniformizowane, gdyż społeczeństwo zatraca możliwości autentycznego samorozwoju (Marcuse, 1991). Dążenie do mądrości i autokreacja w ujęciu krytycznym wymagają przede wszystkim wyzwolenia się człowieka, krytycznego spojrzenia na warunki, w jakich żyje, i na dominujące ideologie określające podstawy jednostkowego i społecznego spełnienia (Habermas, 2004). Wiąże się to z emancypacją, wyzwoleniem, przekroczeniem wzorów jednowymiarowego myślenia i działania - stworzenia własnego transcedującego projektu życia.

Aspekt osiągania mądrości, integralności dotyczy wewnętrznych przełomów dokonujących się w człowieku, dzięki którym porzuca on iluzje, sztywne przekonania. Tworzy siebie, dochodząc do zgody z samym sobą, rezygnując z naśladowania innych i konformistycznego dopasowywania się do zewnętrznych okoliczno- 
ści. Zmiana rozumiana jest jako warunek rozwoju człowieka, ale także jego efekt. Według R. Goulda (1978), do ważnych przejawów rozwoju człowieka dorosłego zalicza się wyzbycie pewnych nastawień, przekonań i oczekiwań wyniesionych z dzieciństwa. Rozwój to zatem nie tylko „przyrost”, lecz także uwolnienie się od czego, co w kolejnej fazie życia jest już anachronizmem. Aktywność autokreacyjna jest stymulacją do wspomagania działań prorozwojowych, poprzez świadome inicjowanie zmiany i poszerzanie perspektywy postrzegania zdarzeń życiowych. Doświadczenie kryzysu może być bodźcem wewnętrznej przemiany, drogą do pełniejszej integracji wewnętrznej. Trudne sytuacje przyczyniają się do tego, że człowiek szuka nowej wiedzy autokreacyjnej (Pietrasiński, 1990). Doświadczenie siebie, wypracowanie siebie jest integrowaniem swojej struktury do wartości osobowych i poprzez te wartości. W dynamikę rozwoju wpisana jest również dezintegracja. Egzystencja osoby nie jest bowiem prostym, bezkonfliktowym wzrostem, przystosowaniem, funkcjonowaniem. Jest ona w pewnym stopniu zawsze walką, zdobywaniem siebie, przezwyciężaniem, trudem (Kobierzycki, 1989).

Doświadczenie życiowej zmiany pomaga w osiąganiu mądrości życiowej zwłaszcza wtedy, gdy osoba w sposób świadomy konfrontuje się sama z sobą, swoimi oczekiwaniami, wyobrażeniami i pomysłami dotyczącymi przeszłych zdarzeń. Przełomy mogą się nasilać w pewnych okresach życia, kiedy zmienia się perspektywa i ogląd własnych działań oraz doświadczeń - przykładem jest przełom połowy życia ujawniający się w okresie średniej dorosłości. Zbliżanie się do tzw. ,„półmetka” może sprzyjać zarówno doświadczeniu kryzysu zwłaszcza wtedy, kiedy człowiek zaniedbuje ważne dla siebie wartości, ale także dokonywaniu bilansu, transformacji dotychczasowego stylu życia i autorefleksji. Doświadczeniom biograficznym w wieku średnim towarzyszą często konflikty, zmiany, a także przejawia się poszukiwanie własnej pełni, dążenie do integracji wewnętrznej (Jung, 1971; Levinson, 1989; Obuchowski, 1985). Z jednej strony jest to okres życia sprzyjający stabilizacji poprzez możliwość zdobycia na tym etapie określonej pozycji zawodowej, statusu społecznego, określonej i bezpiecznej sytuacji rodzinnej (Obuchowski, 1985). Z drugiej strony, około czterdziestego roku życia, który umownie traktowany jest jako „,połowa życia”, ujawniają się nowe tendencje i potrzeby sprzyjające autorefleksji i przemianie. W okresie średniej dorosłości mają szansę ujawnić się nowe aspekty aktywności twórczej, a także potrzeba dążenia do mądrości oparta o wypracowywanie sobie symbolicznej nieśmiertelności poprzez podejmowanie aktywności na rzecz działań o nieprzemijającej wartości, ukierunkowanych na inne pokolenia (McAdams, 2001).

W kontekście badań nad biografiami dotyczącymi przełomu wieku średniego interesująca wydaje się analiza okoliczności, jakie towarzyszą wewnętrznym przemianom w tym okresie, jak zmieniają się narracje biograficzne i opowieść o życiu. Jakościowy opis momentów przełomu w wieku średnim może (i powinien) stanowić analizę czynników, które sprzyjają podejmowaniu ryzyka twórczego rozwoju, transformacji życia po osiągnięciu już pewnej stabilniej sytuacji ży- 
ciowej. Z perspektywy badań biograficznych nad twórczością szczególnie istotne jest ujawnianie specyfiki twórczości i autokreacji w przypadku osób już w pewien sposób ukształtowanych i dojrzałych, konfrontujących się z poczuciem przemijania, straty, z ograniczeniami możliwości wielokierunkowej ekspansji w swoich działaniach, a jednocześnie mających pewien zasób doświadczeń, środków pozwalających łączyć potrzeby autokreacyjne z dążeniem do mądrości życiowej, spełnienia, wewnętrznej integracji, harmonii i z działaniami na rzecz innych. Analiza biografii osób w okresie średniej dorosłości ukazuje inne aspekty aktywności twórczej i autokreacyjnej niż w przypadku osób bardzo młodych (wczesna dorosłość), które określają i kształtują swoją drogę dorosłego życia, mają perspektywę wyboru wielu możliwych kierunków działania i kreacji siebie, swoich ról życiowych i zadań. Natomiast autokreacja w przypadku osób w wieku średnim wymaga świadomej decyzji związanej często ze stratą czy rezygnacją z określonych warunków życia i funkcjonowania codziennego, które zostały określone i wypracowane na wcześniejszym etapie życia. Autokreacja łączy się z restrukturyzacją określonej już (a nie kształtującej się dopiero) wizji życia, przekształceniem działań, złamaniem bezpiecznej rutyny. Kreacja wykracza poza perspektywę własnej biografii, zakładać należy również, że towarzyszy jej potrzeba osiągania mądrości życiowej.

\section{Literatura}

Biswanger L., 1963, Being-in-the-world: Selected papers of Ludwig Binswanger, Basic Books, New York.

Boss M., 1977, Existential foundations of medicine and psychology, Aronson, New York.

Dąbrowski K., 1979, Dezintegracja pozytywna, PIW, Warszawa.

Demetrio D., 2000, Autobiografia. Terapeutyczny wymiar pisania o sobie, Impuls, Kraków.

Fromm E., 1973, The Anatomy of Human Destructivness, Holt, Rinehart and Winston, New York.

Frankl V. E., 1963, Man's Search for Meaning, Washington Square Press, New York.

Gałdowa A., 2000, Powszechność i wyjątek. Rozwój osobowości człowieka dorostego, Uniwersytet Jagielloński, Kraków.

Giddens A., 2001, Nowoczesność i tożsamość. „Ja” i społeczeństwo w epoce późnej nowoczesności, PWN, Warszawa.

Gould R. L., 1978, Transformations: Growth and change in adult life, Simon and Schuster, New York.

Habermas J., 2004, Działanie komunikacyjne i detranscendentalizacja rozumu, przeł. W. Lipnik, Oficyna Wydawnicza, Warszawa.

Hermans H. J. M., Kempen H. J. G., 1993, The Dialogical Self: Meaning as Movement, Academic Press, San Diego.

Jung C. G., 1971, The stages of life, [w:] J. Campbell (ed.), The protable Jung, Penguin, New York, s. 3-22.

Jung C. G., 1976, Archetypy i symbole. Pisma wybrane, Czytelnik, Warszawa.

Kobierzycki T., 1989, Osoba. Dylematy rozwoju. Studium metakliniczne, Pomorze, Bydgoszcz.

Levinson D. J, 1989, A conception of adult development, „American Psychologist”, 41, s. 3-13. 
Mangione L., 1993, Life themes manifest through artistic creativity, [w:] J. Demick, P. M. Miller (eds), Development in the Workplace, Lawrence Erlbaum Associates, Publishers, Hillsdale, s. 109-128.

Marcuse H., 1991, Człowiek jednowymiarowy: badania nad ideologia rozwiniętego społeczeństwa przemysłowego, Wstęp W. Gromczyński, tłum. S. Konopacki, Z. Koenig i in., PWN, Warszawa.

Maslow A., 2006, Motywacja i osobowość, tłum. J. Radzicki, Wydawnictwo Naukowe PWN, Warszawa.

McAdams D. P., 1989, The development of narrative identity, [w:] D. M. Buss, N. Cantor (eds), Personality Psychology, Springer Verlang, New York, s. 160-174.

McAdams D. P., 2001, The Person: An Integrated Introduction to Personality Psychology, $3^{\text {rd }}$ ed., Hartcourt Brace College Publishers, Forth Worth.

McAdams D. P., de St. Aubin E., 1992, A theory of generativity and its assessment through self-report, behavioral acts, and narrative themes in autobiography, ,Journal of Personality and Social Psychology", 62, s. 1003-1015.

McAdams D. P., 2008, Personal narratives and life story, [w:] O. John, R. Robins, L. Pervin (eds), Handbook of Personality Theory and Research, Guilford Press, s. 242-262.

Obuchowski K., 2000, Człowiek intencjonalny, czyli o tym, jak być soba, REBIS, Poznań.

Obuchowski K., 1985, Adaptacja twórcza, Książka i Wiedza, Warszawa.

Oleś P. K., 2000, Psychologia przełomu połowy życia, Towarzystwo Naukowe Katolickiego Uniwersytetu Lubelskiego, Lublin.

Oleś P. K., 2003, Wprowadzenie do psychologii osobowości, Wydawnictwo Naukowe SCHOLAR, Warszawa.

Oleś P. K., 2011, Dialogowe Ja, zarys teorii, inspiracje badawcze, ciekawsze wyniki, [w:] P. K. Oleś, M. Puchalska-Wasyl (red.), Dialog z samym soba, Wydawnictwo Naukowe PWN, Warszawa, s. 143-171.

Pietrasiński Z., 1990, Rozwój człowieka dorosłego, Wydawnictwo „Wiedza Powszechna”, Warszawa.

Pietrasiński Z., 2008, Ekspansja pięknych umystów. Nowy renesans i ożywcza autokreacja, Wydawnictwo CIS, Warszawa.

Reker G. T., 2000, Theoretical perspective, dimension, and measurement of existential meaning, [w:] G. T. Reker, K. Chemberlain (eds), Exploring Existential Meaning, Sage, Thousand Oaks, s. 39-55.

Rogers C., 1991, Terapia nastawiona na klienta. Grupy spotkaniowe, Thresaurus Press, Juniorzy Gospodarki, Wrocław.

Tokarska U., 2002, Narracja autobiograficzna $w$ terapii i promocji zdrowia, [w:] J. Trzebiński, Narracja jako sposób rozumienia świata, GWP, Gdańsk, s. 221-261.

Trzebiński J. (red.), 2002, Narracja jako sposób rozumienia świata, GWP, Gdańsk, s. 17-78.

Wortham S., 2000, Interactional positioning and narrative self-construction, Narrative Inquiry, 10, s. $157-184$. 